\title{
Australian universities face disruptive changes
}

Sydney. Australia's education minister, Amanda Vanstone, announced last week that the government is to cut university funds by 5 per cent, despite an agreement to keep budget decisions secret until later this month.

The A\$1.8-billion (US\$1.4-billion) cut will be phased in over four years. To sweeten the pill, Vanstone pledged to fulfil a promise to boost funds for research infrastructure by A $\$ 90$ million and for postgraduate awards by $\mathrm{A} \$ 40$ million over the same period.

The cut is less than had been feared.
Vanstone hinted in May that a cut of up to 12 per cent might be imposed (see Nature 381, 456; 1996). This prompted a prolonged and angry campaign by academics, including strikes by university students and staff. Protests are continuing, however, particularly over increases in fees that double the cost to students taking science degrees.

The cuts are part of an attempt by prime minister John Howard's new Conservative government to reduce public spending to trim a budget deficit of $\mathrm{A} \$ 10$ billion, without raising taxes. In their election campaign, the

\section{Report advises against privatization}

London. A UK government committee set up to investigate options to privatize three public sector research establishments including the British Geological Survey (BGS), is understood to have advised ministers against private ownership.

The committee submitted its report to Ian Lang, president of the Board of Trade, at the end of last month. A separate 'competitiveness' committee of cabinet ministers will consider the review in October. Controversially, the three establishments do not officially know the report's contents.

The report is part of the government's continuing 'prior options review', which is investigating the possibility of privatizing more than 40 public-sector research establishments. It also covers the Centre for Coastal and Marine Sciences in Plymouth and the Centre for Ecology and Hydrology in Oxfordshire, as well as the BGS. All three establishments form part of the Natural Environment Research Council (NERC).

None will comment on the steering committee's recommendations. But all have vigorously lobbied against privatization. The BGS even published in full its submission to the steering committee.

Peter Cook, director of the BGS, says that it is not possible for a private-sector organization to own or manage the BGS without compromising the organization's "excellence, impartiality, relevance and authority". The BGS is already being run on business lines, he says. Profits from a privatized BGS would "not necessarily benefit the science".

But ministers are not bound by the recommendations. The first batch of establishments reviewed - including some linked to the Biotechnology and Biological Sciences Research Council and the Ministry of Agriculture - are now undergoing a second review of future options. Ministers are believed to have disagreed with the recommendations of the original prior-options review committee.

The government's decision to withhold the steering group recommendations from the three establishments has fuelled a growing controversy about the lack of openness of the prior options review process. The recommendations for the first batch of reviews have also been kept secret.

Cook says that while he understands the constraints under which ministers and civil servants operate, restricting the report to ministers and the steering group "has not been helpful".

But John Krebs, chief executive of NERC, points out the steering committee's report is not the result of "a one-way process". All three research establishments

\section{兽} dents of medicine, dentistry, veterinary science and law will pay 125 per cent more.

Vanstone says that the fee increases are fair because of the enhanced earning power of graduates. Graduates will now be obliged to begin grant repayments (through taxation returns) when their salaries reach $A \$ 20,700$, compared with the current level of $\mathrm{A} \$ 28,500$.

Universities will be allowed, for the first time, to charge full fees to some Australian students, an option previously available only for students enrolling from overseas.

Joe Baker, president of the Federation of Scientific and Technological Societies, has not been silenced by his recent appointment to the prime minister's Science and Engineering Council from branding the effect of the cuts on science as giving "all the wrong signals".

Baker questioned "the logic in making science a less attractive career to our best and brightest students" and contradicted Vanstone's claim that graduates have higher incomes. "Too many young research scientists face underpaid, uncertain careers on short-term funding."

Political manoeuvring has begun in an attempt to block the cuts, especially the increased course fees, in the Senate, where the balance of power is held by the opposition Labor Party, the Australian Democrats and three independents.

Peter Pockley 